chloramphenicol was administered in a dosage of $23 \mathrm{~g}$. over nine days. Within four days all the symptoms had subsided, and on October 5 the patient, then fully recovered, was discharged from hospital. (This case was described by Curtin (1949) in his group of paratyphoid fever cases treated with chloramphenicol.)

Further Investigations.- The patient's blood, taken on August 31, was reported to agglutinate Salm. paratyphi $B$ $H$ up to 1 in 2,500 and non-specific salmonella up to 1 in 50. It did not agglutinate Salm. typhi $\mathrm{H}$ and $\mathrm{O}$ or Salm. paratyphi $B$ O. On September 12 the paratyphoid organisms cultured from the faeces were reported to belong to phage type Taunton. After treatment the patient's stools were reported free from pathogens on September 23 and 30 and on October 3 and 7 . On October 13 her serum still agglutinated Salm. paratyphi $B$ H 1 in 2,500 . The other members of the patient's household-her husband, son, and daughter-submitted samples of faeces on October 3 , and these were reported free from pathogens. As the patient was the only case of paratyphoid fever due to phage type Taunton bacilli in the district in 1949, it was not possible to ascertain the source of infection. In that year the other local cases of paratyphoid fever were due to organisms of phage type $3 \mathrm{a}$ and epidemiologically related to a small outbreak in the adjoining areas of Hebburn and Jarrow.

\section{Second Attack}

On June 24,1954 , the patient, who had been quite healthy since the previous illness, again became ill with rigors, headache, pain in the back, and painful micturition. Next day she suffered from diarrhoea and vomiting, which continued until June 28, when she was sent to hospital for investigation. On admission the patient, now aged 45, complained of headache and difficulty in opening her eyes and resented any movement of her neck. Her tongue was coated. There was slight distension of the abdomen together with generalized tenderness, but the spleen was not enlarged. Although there was a slight dry cough, chest examination revealed no abnormality. Over the lower half of the abdomen there were several rose-red papules. The temperature was $102.4^{\circ} \mathrm{F} .\left(39.1^{\circ} \mathrm{C}\right.$.) and pulse 100 . The white-cell count was 6,000 , and the cerebrospinal fluid, the urine, and a chest skiagram showed no abnormalities. The patient was put on a course of $14 \mathrm{~g}$. of chloramphenicol. The stools taken after admission were reported to contain Salm. paratyphi $B$ on July 2 , by which day she was much improved, the temperature had resumed the normal level, and the papular rash had faded. Subsequently progress was uninterrupted and she was discharged on July 12 , still excreting the organism in the faeces.

Further Investigations. - The organisms found in the patient's faeces of June 29 were reported on July 15 to belong to the phage type Taunton. A sample of her blood taken on July 5 agglutinated the standard suspensions of Salm. paratyphi $B \mathrm{H}$ in a dilution of 1 in 5,000, Salm. paratyphi $B O$ in a dilution of 1 in 125 , and non-specific salmonella $H$ in a dilution of 1 in 25 . Tested against the patient's own organisms, the blood agglutinated these in $\mathrm{H}$ suspension up to 1 in 2,500 and in $O$ suspension up to 1 in 125. On July 26 the patient's blood, retested, agglutinated standard Salm. paratyphi $B$ in $H$ suspension in 1 in 2,500 dilution and in $O$ suspension 1 in 50. Against her own organisms the agglutination titre was 1 in $2,500 \mathrm{H}$ and 1 in $25 \mathrm{O}$. The patient's contacts-her husband and their two children-once again submitted samples of faeces, which were reported on July 10 to be free from pathogens.

In this second attack the patient was again an isolated case of paratyphoid fever, but she volunteered the information for the first time that during the period before each of her attacks she had been helping to care for a neighbouring old lady, Mrs. X, who lived alone. In June, 1949, Mrs. X, then $\mathbf{8 0}$ years old, had an attack of diarrhoea with incontinence, during which she was bathed by the patient. Mrs. X was admitted to a geriatric ward of another hospital on June 20,1949, with low-grade pyrexia and in a drowsy and stuporous condition. The pyrexia continued for 10 days, and she recovered to be discharged on July 20, 1954. Her faeces were not examined at that time. Since Mrs. X's illness the patient had given regular assistance two or three times a day to her neighbour, whose faeces were therefore submitted to the laboratory, with the result that they were reported on July 22,1954 , to contain Salm. paratyphi B, later confirmed as of phage type Taunton. Mrs. X had no recent complaint of illness, and her general state of health was that appropriate to her age.

I am indebted to Dr. R. Norton for the bacteriological and serological findings quoted in this case and to Dr. E. S. Anderson for the phage-typing of the organisms.

\author{
JAMES GRANT, M.D., D.P.H., \\ Medical Officer of Health, Gateshead \\ Medical Superintendent, Sheriff Hill Infectious Diseases Hospital. \\ REFERENCE \\ Curtin, M. (1949). British Medical Journal, 2. 1504.
}

\section{Abdominal Apoplexy due to Spontaneous Rupture of Right Gastric Artery}

Spontaneous intraperitoneal haemorrhage in the male is a rare condition, and for this to occur without any demonstrable pre-existing pathological condition is extremely unusual. Brewer and Marcus (1948) reviewed the literature, and succeeded in collecting 28 cases, in most of which hypertension was present. In 10 cases, including their own, no bleeding-point could be found, and the commonest known site of bleeding was the left gastric artery, which was responsible for three cases. Only one case of spontaneous haemorrhage from the right gastric artery appears to have reached the literature, and this was in a known hypertensive. The following case, therefore, of massive spontaneous haemorrhage from rupture of the right gastric artery in a man in whom no other pathological condition could be found may, I think, be regarded as unique.

\section{CASE RePort}

A man aged 59 was admitted to hospital at 6.15 p.m. on February 3,1955. His health had always been good, until one hour before his admission, when he had suddenly had excruciating pain in his left abdomen while quietly changing in his hotel. The pain increased, and on admission he was obviously shocked and in great pain, and on examination was found to have a tender, rigid abdomen, with shifting dullness in the left flank.

He was taken to the theatre and the abdomen opened by a left paramedian incision. A large quantity of blood filled the peritoneal cavity, and as this was being removed a rapid search was made for the bleeding-point. The more usual sites gave no answer, and, as his condition was rapidly deteriorating despite a transfusion, and his pulse had become imperceptible, one began to despair. The blood seemed to be coming from the upper abdomen, and the idea then occurred of gripping the free edge of the lesser omentum. This was immediately successful, and the blood no longer welled up. While keeping one's fingers in this position the abdomen was emptied of blood, and when the grip was then relaxed a spurt of blood was seen to come from the right gastric artery, about 1 in. $(2.5 \mathrm{~cm}$.) from the pylorus. The vessel was clamped and the ruptured segment removed for section. The abdomen was closed.

Post-operative progress was completely uneventful, and the patient left hospital on February 19. He was not hypertensive, no other abnormality could be found, and the histological report on the segment of vessel stated that the rupture had occurred in what appeared to be an otherwise perfectly normal vessel.

ROBIN BURKITT, M.D., F.R.C.S., F.R.C.S.I., Upton Hospital, Slough.

REFERENCE

Brewer, A. C., and Marcus, R. (1948). Brit. J. Surg., 36, 198 